\title{
Tools for the Implementation of the Sustainable Development Goals in the Design of an Urban Environmental and Healthy Proposal. A Case Study
}

\author{
Rafael Herrera-Limones ${ }^{1}(\mathbb{D})$, Maria LopezDeAsiain ${ }^{1, *(\mathbb{D})}$, Milagrosa Borrallo-Jiménez ${ }^{1}(\mathbb{D}$ \\ and Miguel Torres García ${ }^{2}$ (D) \\ 1 Instituto Universitario de Arquitectura y Ciencias de la Construcción, \\ Escuela Técnica Superior de Arquitectura, Universidad de Sevilla, Avd. Reina Mercedes 2, \\ 41012 Seville, Spain; herrera@us.es (R.H.-L.); borrallo@us.es (M.B.-J.) \\ 2 Departamento de Ingeniería Energética, Escuela Técnica Superior de Ingeniería, Universidad de Sevilla, \\ Camino de los Descubrimientos s/n, 41092 Seville, Spain; migueltorres@us.es \\ * Correspondence: mlasiain@us.es
}

\section{check for} updates

Citation: Herrera-Limones, R.; LopezDeAsiain, M.; Borrallo-Jiménez, M.; Torres García, M. Tools for the Implementation of the Sustainable Development Goals in the Design of an Urban Environmental and Healthy Proposal. A Case Study. Sustainability 2021, 13, 6431. https://doi.org/ $10.3390 /$ su13116431

Academic Editor:

Pilar Mercader-Moyano

Received: 21 April 2021

Accepted: 1 June 2021

Published: 5 June 2021

Publisher's Note: MDPI stays neutral with regard to jurisdictional claims in published maps and institutional affiliations.

Copyright: (c) 2021 by the authors. Licensee MDPI, Basel, Switzerland. This article is an open access article distributed under the terms and conditions of the Creative Commons Attribution (CC BY) license (https:// creativecommons.org/licenses/by/ $4.0 /)$.

\begin{abstract}
This article presents a methodological proposal to address the urban issue from the perspective of the Sustainable Development Goals (SDGs). Different tools have been developed for this purpose: the Aura Method and the Aura Matrix. The Aura Matrix of relationships built from the SDGs, along with the conceptual proposals to which the project must respond, allows for the definition of a methodological framework of action, defined as the Aura Method, applicable to any project that aims to respond to the urban scale from a more sustainable and healthy approach and within the framework of the above-mentioned goals. Two proposals for the Solar Decathlon Latin America of the Aura Team from the University of Seville (2015 and 2019) in Cali, Colombia, and their comparison, are presented as case studies. The scope of the 2019 proposal based on the use of these tools is more rigorous and bold with respect to the requirements defined by the SDGs than the 2015 proposal, based on the millennium goals. This reinforces to a great extent the resilience of the urban scope under study and its capacity to face serious situations in terms of citizens' health, such as the pandemic we are currently suffering, and improves life quality. The main findings lay on the defined Aura Matrix and Aura Method tools as pragmatic opportunities to translate conceptual approaches such as G3: 'Ensure healthy lives and promote well-being for all at all ages' into practical decisions and urban design proposals to improve the quality of life and health of citizens.
\end{abstract}

Keywords: sustainable development goals; urban design; neighborhood regeneration; competition; architectural education; indoor environmental quality; health

\section{Introduction}

The Sustainable Development Goals (SDGs) enunciated by the New Urban Agenda [1] in Quito, 2015, are a reference framework recognized worldwide [2,3]. However, its incorporation as a strategy for innovative development in architectural and urban design has been hardly investigated in practical terms, except for the political-normative field, according to some authors [3-9], or the management $[10,11]$ or biodiversity conservation [12] fields, according to others. The references that we can find to research in the urban field focus on establishing a generic framework $[13,14]$ approaching the complexity of the problem and its numerous requirements $[7,12,15]$, without defining specific design tools or strategies that may allow their practical application or their specific assessment by means of indicators [16]. There are also some advances in this framework related to the design of very specific elements of construction systems [2] or fixtures [11,17], also in the building environment [3,18-20], but the review carried out in the main research databases (Web of Science and Scopus), shows that specific urban architectural design 
aspects are scarcely developed in depth. Thus, the use of the theoretical-practical concept of the SDGs [21] as a design approach strategy represents an innovation in the methodological field of architectural and urban design, as well as an alignment with international urban development policies. The perspective incorporates the way to approach the development of the city from an inclusive point of view [22,23], taking into account issues such as climate change, cultural identity, reduction of poverty levels, drinking water, natural resources and decent life conditions, especially health conditions. In addition, approaching the SDGs in the COVID-19 context, thus giving credit to the unavoidable relationship between urban quality of life and health [24], is a necessity and a responsibility that architecture and urban design must assume. The opportunity offered by this approach is greatly relevant given the current situation. Beyond the search for immediate solutions, there is clearly a need to work on prevention from an architectural disciplinary approach that includes-in practical terms - the capacity of architecture and urban space [25] to guarantee decent conditions of life quality and health [25] for citizens with the least resources.

The Aura Strategy used by the Solar Decathlon Team of the University of Seville in the Latin American Solar Decathlon (both in the 2015 and 2019 editions) seeks to put into practice a research-based educational methodology [26], where the concept of sustainability underlies cross-sectionally the understanding that this approach can serve as a catalyst for student engagement [27]. Likewise, the Aura Strategy was initially formulated based on the Millennium Goals, which remained in force until September 2015, and developed further [21] based on the key transformation of these goals through the 17 Sustainable Development Goals (SDGs) [5], which encourages students to work according to the current international premises and be aware of the challenges that the field of architecture has to face nowadays, due to the pandemic, and in the near future.

It is the sustainable aspect of the urban environment that is considered the main focus of this article, which intends to explain how, in this context, the Aura Strategy produces the subsequent development of the Aura 1.0 and Aura 3.1 Projects (corresponding, respectively, to the Solar Decathlon Latin America Competition 2015 (SDLac15) and the Solar Decathlon Latin America Competition 2019 (SDLac19)), intertwined with the Millennium Goals in the first case and with the SDGs in the second. That is: starting from the implementation of these goals to use them as a tool that can eventually become an Urban Sustainable Healthy Proposal. To carry out the integration of the SDGs in the design of the SDLac19 Aura Project, the Aura Matrix tool is constructed and the Aura Method is defined, which, starting from the experience of the Aura Project 1.0, allows us to improve the initial results for the subsequent Aura Project 3.1 experience.

\subsection{SDGs_-Sustainable Development Goals and Their Importance}

In order to confront the world's rapid urbanization processes in the coming thirty years [28], the 2030 Agenda for Sustainable Development and the SDGs were approved in September 2015, with the acknowledgment of culture and heritage as axes for sustainable urban development. This Agenda is a roadmap to fight poverty and inequality [29], with a focus on people, the planet, prosperity, peace and partnership [30].

The 17 Objectives and 169 Goals defined by the Agenda are based on the Millennium Development Goals (which remained in force until 2015), although they also include new spheres such as climate change, economic inequality [5], innovation, sustainable consumption, peace and justice, and health, among other priorities. The Objectives are interlinked so that the success of one directly affects the rest. The main input lays on income, education and life expectancy in terms of health as key factors which determine the Human Development Index (HDI) [31]. The SDGs convey a spirit of collaboration and pragmatism for choosing the best options to improve life, in a sustainable manner, for future generations. The SDGs are the most inclusive development processes that the world has ever seen. They cover the fundamental causes of poverty and foster collaboration in order to achieve a positive change for the benefit of the world and its inhabitants. 
Despite the opportunity it presents, incorporating SDGs into architectural design practice is neither easy nor immediate. The complexity of the objectives planned from a single point of view and the diversity of implications [2] make the extrapolation to the field of architecture extremely difficult. The challenge, therefore, is to establish an objective, technical and architectural strategy, which allows the introduction of SDG concepts from a mutually dependent, yet sufficiently pragmatic, approach, in order to be able to extrapolate these concepts into technical and objective actions and decisions [32]. In order to accomplish this, other previous experiences of important authors have served as a reference for the methodological development $[2-4,9,20]$. In this sense, this research project has found in the Solar Decathlon competitions a potential resource for experimenting with the methodology defined for the incorporation of SDGs into architectural design practice.

\subsection{The Field of Educational Experimentation of SD Competitions}

University education is currently undergoing a major transformation. One of the trends in educational innovation with the best results is the set of integrated curriculum proposals $[33,34]$. In the case of architectural education, the Aura Strategy develops the Bauhaus tradition and the incorporation of new teaching methodologies, including a mix between different disciplines. The Strategy incorporates issues such as integrated curriculum [35], transdisciplinarity [36,37], transversality and learning methods through problem solving [38].

The SD competitions are a great opportunity for exploration, since they are based on a line of research whose fundamental purpose is the search for living models [39] that minimize the environmental impact based on the convergence toward H2020, according to UNESCO's SDGs for 2030 [40] and the related Higher Education Sustainability Initiative (HESI) [27]. This is based on the conviction that in the search for more habitable, healthy, resilient and, therefore, sustainable city models, sensitive to bioclimatic strategies of adaptation to the climate and the supporting ecosystem, and aimed at maximizing efficiency in the use of resources, healthy future building archetypes [41] will be found and, particularly, new urban models of approach to the city will be defined [40]. The time has come to address SDGs in higher education [27,40], meaning that their necessary innovative practical implementation [42] is crucial for this research.

\subsection{The Aura Conceptual Strategy}

Based on Christopher Alexander's theory of systems that generate systems [43] and applying holistic systems at different scales [44], Project Aura is defined as one of these systems, by promoting the idea of not creating or projecting something specific, but something that can continue to create more systems cyclically, breaking with the typical scheme of relations of the tree city. This theory is strongly supported by the concept of Production and Social Management of the Habitat [45], that starts from the hologrammatic principle according to which 'the whole is part of parts, just as the parts are part of the whole', that is, nothing is understandable if the synergies between its parts are extracted from the whole. It therefore reinforces the idea of a society that makes decisions as a whole about everything that happens in its city [40], based on the collaborative relationship between the three groups of agents that define a city: Politicians, Technicians and Citizens [46]. At present, these have a totally different weight in the decision making process, a fact that the team will aim to balance, in order to give the citizens of Cali the weight they should have. This idea is linked to another concept: the commons, as a result of citizen action in an intermediate space of autonomy between the state and the market, and which is here particularized from our share as technicians betting on open knowledge, a clear example of the commons. Following authors such as Juan Freire [47], we use social technologies (defined as assemblies of people + digital technology) for the different phases of the project: mapping of actors, massive surveys of the population, consultation of active associations in the municipality, dumping of information derived from citizen information repositories, 
ideas laboratories, participatory workshops, etc. The Aura Project relies on the social, political and economic transformative capacity of open knowledge.

Small-scale urban interventions are now considered necessary as a start for new urban techniques [31]. This is where the concept of Cities in Transition appears, as an urban theory that proposes to raise awareness to the need for social union around shared objectives, health, income and education from an architectural perspective, a fact that supports the citizens' participation [48] in the improvement of their neuralgic center, the city. This theory is based on several applicable principles:

- Collective Management of Housing Rehabilitation, support for heritage and its reuse as the most effective measure to support the environment.

- Collective Management of Public Space, such as the generation or rehabilitation of obsolete or disused spaces within the city.

- Accessibility and Sustainable Mobility, facilitating communications and interrelations between individuals.

- Socio-Environmental Sensitization, Training and Education, generating in the individual a citizen consciousness which relies on a balanced local management of ecosystems that ensures health and resilience conditions.

- Food Sovereignty, strengthening community gardens with ecological management and promoting short marketing channels for local farmers.

- Energy Sovereignty, promoting energy consumption and guarantying habitability in terms of comfort and health.

Everything described above is reflected in the strategic lines that the team defines as essential for its performance in Cali. The experiences of SDLac15 and SDLac19 do not differ regarding this objective, but they do differ regarding the methodology used in their development. In the case of SDLac19, the methodology is systematized by defining the Aura Method and the Aura Matrix, which constitute interesting tools that can help obtain more precise results, clearly involved with the SDGs. This way, the Aura Conceptual Strategy transcends the residential and invokes the urban from a perspective that incorporates the premises that are defined generically from the SDGs. The main strategy is to translate these generic requirements into concrete architectural decisions, not only based in urban forms as usual [14], but also consistent with the reality, the place and the needs of its inhabitants, in order to improve their quality of life in terms of health and well-being. Thus, the research goal is to develop two different tools, which are useful for the strategy presented above. These tools consist of the Aura Matrix tool and the definition of the Aura Method as a methodological process.

\section{Methodology}

The methodology used is qualitative, based on a constructivist approach that raises the need to understand reality from the subjective field and according to the contributions and approaches of all of those involved in the research [12]. Therefore, the present research adopts a qualitative research approach for data collection and analysis, following other studied authors [12,14]. The methodology is based on the following phases:

- The study of the state of the art in terms of the integration of the SDGs in the architectural design debate is carried out.

- The opportunity presented by the Solar Decathlon competitions is defined as a potential field of experimentation, given its approach linked to the improvement of the habitat in terms of sustainability and its educational capacity, guaranteeing health and increasing resilience of communities.

- The previous experiences developed for the competition are analyzed as a starting context: Aura conceptual strategy in Latin America 2015 and its initial proposal for Latin America 2019.

- The Aura Method is defined as a methodological proposal. This Method includes the development of a tool, the Aura Matrix, for the interrelation between the SDGs and the requirements defined by the competition itself. 


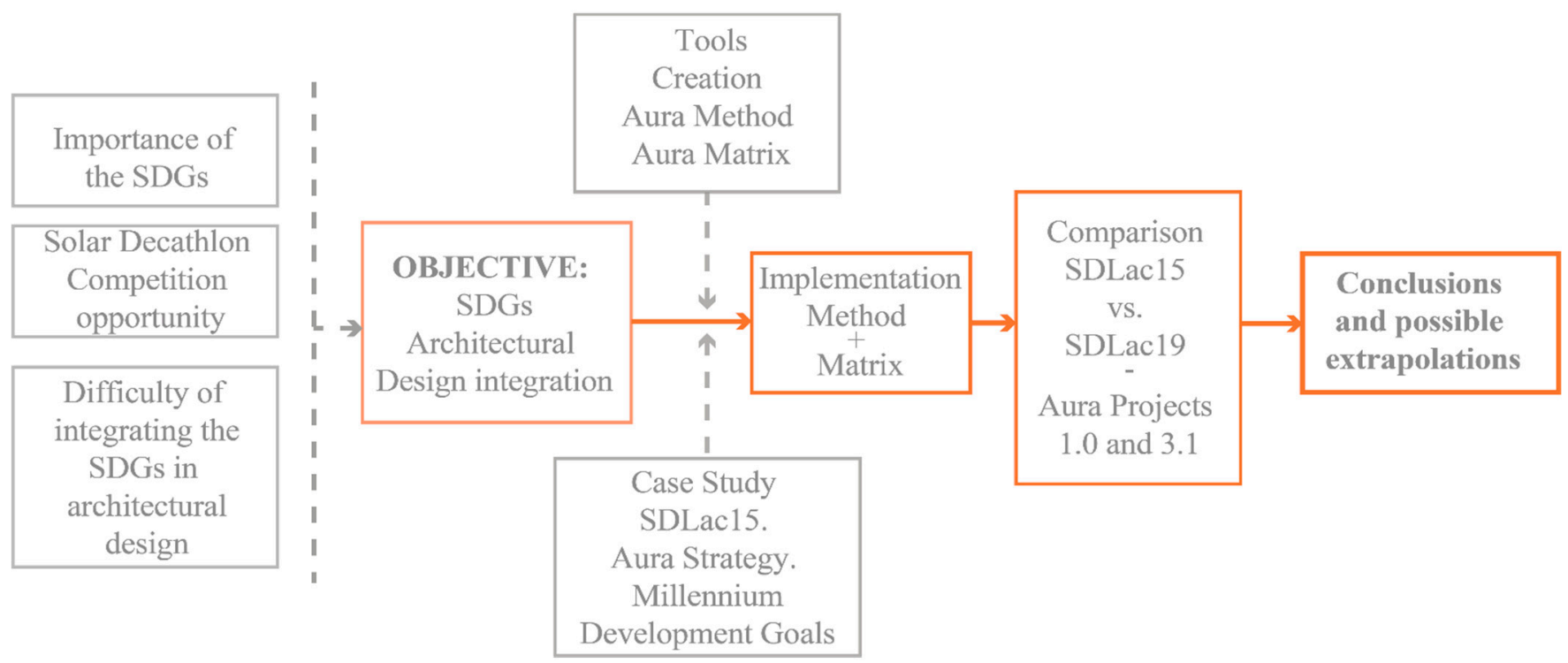

- The application of the Aura Method in the Solar Decathlon 2019 is developed as an experiment by the Team of the University of Seville, resulting in the Aura 3.1 Project submitted to the competition.

- The study analyzes the progress that the Aura Method and the Aura Matrix have brought about in the development of the Project for Latin America 2019 compared to the results of the Project for Latin America 2015 (based on the Millennium Goals).

- Given the obtained results, conclusions are drawn and potential extrapolations are made for all types of future and mainly urban architectural design projects.

- $\quad$ These stages of analysis are represented in Figure 1.

Figure 1. Diagram of the process. Sustainable Development Goals (SDGs). Source: the authors.

\subsection{Definition of the Aura Method}

Starting from the incorporation of SDGs into the design process, the results obtained in SDLac15 (First Prize Communication, Marketing and Social Conscience, First Prize Comfort Conditions, Third Prize Engineering and Construction, Third Prize Innovation and Runner-up Prize Architecture), based on the previous Millennium Goals, demonstrate that the previous approach is based on a project design strategy [49] distinguished with numerous awards and validated by the design results of the project itself, both urban and building-related. However, in urban matters, many of the proposals are not sufficiently defined or appropriate to these new SDGs. Therefore, it is necessary to develop an 'Aura Method' that allows us to consolidate, with the necessary tools, the process that ensures that these SDGs are explicitly referenced and take shape in the final decisions of project design. Health suitability has recently become a priority in terms of approaching the SDGs, and the Aura Method reinforces the importance of this transversal but crucial aspect as the basis for improving resilience in our building environment and cities.

\subsubsection{Generation of the Aura Matrix}

The Aura Matrix is a practical, graphically expressed tool for relating concepts that allows the SDGs to be approached in a systematic and direct way, as well as very quickly, with the requirements defined by the SD competition for the completion of its 10 tests. This matrix is a key tool of the Aura Method and is generated for each specific case during its development. Its generation process for the specific case of SDLac19 is explained below. 


\subsubsection{Phases of the Aura Method}

The Aura Method, designed to systematize a way of dealing with the design of an architectural and urban project that allows the SDGs to be rigorously included, follows the scheme shown in Figure 2 and consists of the following phases:

- Framework definition: The Solar Decathlon Competition, Analysis and Requirements

- Case Study: Latin America Cali, Colombia

- Training and Awareness of Agenda 2030 and SDGs

- Development of the SDG Workshop

- Generation of the SD-SDG Interrelationship Aura Matrix

- Development of the Aura Proposal for the SD 2019 Latin America competition

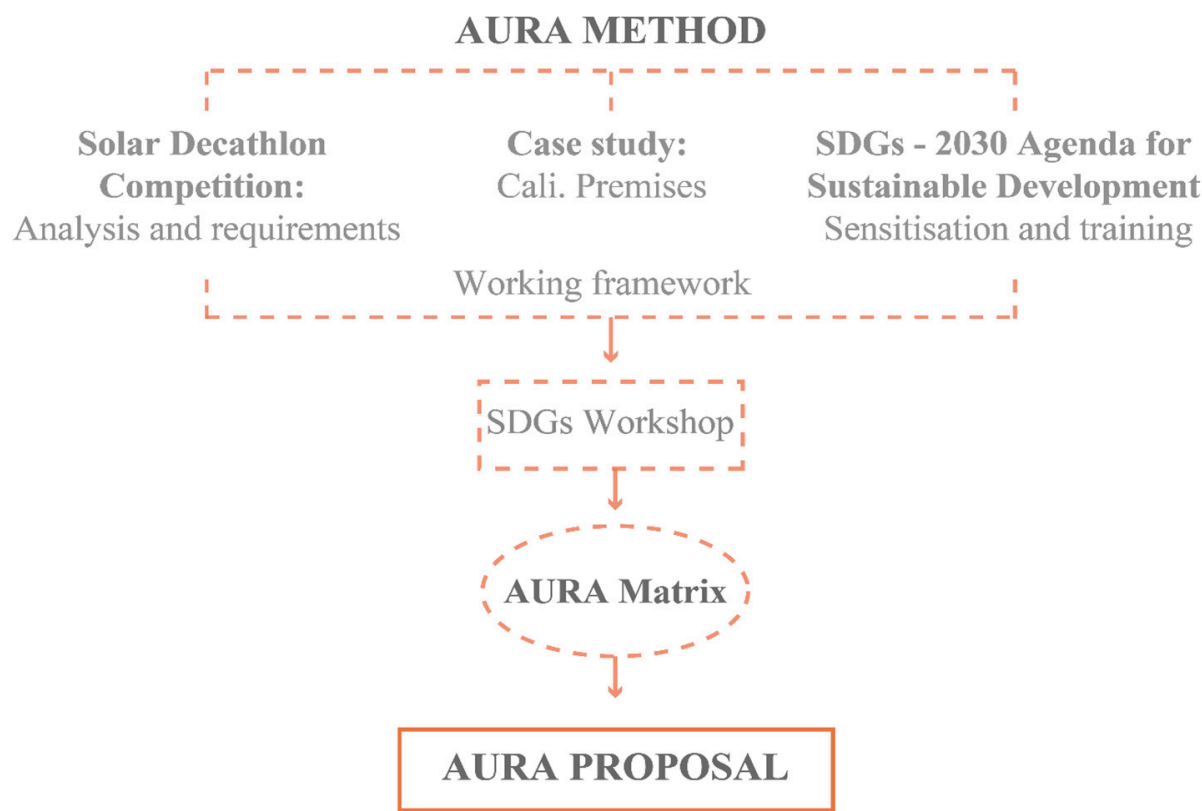

Figure 2. Aura Method diagram. Source: the authors.

The complete development of these phases has made it possible to generate a project for SDLac19, whose characteristics and design decisions explicitly respond to the SDGs, as can be seen below.

\subsection{The Aura Method Application}

2.2.1. Framework Definition: The Solar Decathlon Competition, Analysis and Requirements

The SD competition is centered around the 10 tests mentioned above: Architecture; Energy Efficiency; Engineering and Construction; Comfort, Marketing and Communication; Electrical Energy Balance; House Functioning; Innovation; Urban Design; Affordability; and Sustainability.

The urban issue is part of the initial design phase of the project, and the prototype must be framed within it. However, the prototype construction phase in the Villa Solar requires the adaptation of the urban building proposal to a single-family housing prototype [50] as an experimental case. The definition of the place where the specific urban proposal is made is left to the teams that enter the competition and is always justified based on the needs detected in the city.

As can be seen, the premises and design requirements of the competition itself are perfectly in line with many of the issues defined by the SDGs and are integrated as dynamics or project objectives by the Aura Strategy of the Solar Decathlon Team of the University of Seville. The complexity [51] lies in the multitude of premises that address different scales of action, involve numerous and diverse agents and must respond to the 
regional, territorial and urban components of the site. To this end, the SDLat19 proposal begins by systematizing the scales of action into: individuals, dwellings, neighborhoods, communities and city. The agents involved are systematized into: citizens, social partners, technicians and politicians. Finally, the regional determining factors are systematized by defining four relevant strategies: the construction and/or improvement of social housing in terms of habitability and health, the increase in density, the use of a rational use of environmental resources and the promotion of regional relevance or progress, the latter being understood as sustainable development and not just economic growth.

\subsubsection{Training and Awareness of Agenda 2030 and SDGs}

The Aura strategy defined by the present research project is grounded in a global and transdisciplinary university framework that involves the whole University of Seville. Based on this approach, various actions are designed to raise awareness to the SDGs, with the participation of the coordinating members of the Aura Team. These actions, proposed at the university level as an Awareness and Training Program on the new Agenda 2030, give rise to various training events. All these actions are used for the training of the Decathlete students who participate in the Aura project. In particular, the Awareness Days 'The University of Seville for the Sustainable Development Objectives' are the framework in which the students participate in various forums and transdisciplinary working groups, according to their interests and fields of specialization. The Aura team is made up of students from different disciplines [52] and not only architects and engineers, as was traditionally the case. Therefore, the SDGs and their transdisciplinary scope encourage exchange, global and holistic reflection and cooperation among students of the team itself.

The Conferences are held in the six campuses of the University of Seville, with 62 specialized conferences on the most varied topics, covering the spectrum of the 17 Sustainable Development Goals and complemented by subsequent debates. The entire Aura Team also participates in the round tables held at the School of Architecture, whose objective is to deepen the understanding of objectives 9-'Industry, innovation and infrastructure. Building resilient infrastructures, promoting inclusive and sustainable industrialization and fostering innovation' — and 11-'Sustainable cities and communities. To make cities and human settlements inclusive, safe, resilient and sustainable', more specifically with regard to architectural-engineering solutions with a direct impact on the framework of the experimental competition under development-and 'Goal 3: Ensure healthy lives and promote well-being for all at all ages', focused on the great challenges that are being addressed today. These round tables are approached from four thematic areas: production, territory, city and community; and during them, the debate is coordinated by an expert in the field, bringing together both decathlete students as representatives of the local and regional administration and teachers and research experts, enriching the speeches and reflections and outlining practical approaches to the various issues. The conclusions of these debates constitute the basis on which the strategic lines of integration of the SDG of the Aura Project are organized, which allow the concepts transmitted from the Objectives of Sustainable Development to be approached in a broad and inclusive manner.

\subsubsection{SDGs Workshop Development and Generation of the SD-SDGs Aura Matrix Interrelationship}

After the awareness development process, a workshop is held with the aim of defining the strategic lines of integration of the SDGs in the design of the architectural project of the Aura Team for the SDLat19. This workshop is developed in several phases: Brainstorming session; Definition of priority strategic lines; Categorization and organization of the strategic lines in thematic areas. Decathlete students as well as numerous expert teachers in different specializations and disciplines and the teaching staff who are members or collaborators of the Aura Team attend the workshop. The workshop lasts for six hours, the first two being dedicated to brainstorming and debating ideas, based on the previous approach defined by the Aura Conceptual Strategy, that includes the local premises of the context in Cali, Colombia. The following three hours are dedicated to the construction of the Aura 
Matrix, that relates the 17 SDGs to the 10 specific tests of the Solar Decathlon competition, by defining the strategic lines. Finally, the last hour is dedicated to the categorization of these lines in the seven thematic areas defined by the Aura Project. It is relevant to indicate that it is the decathlete students who make the final decisions regarding the strategies and their categorization, with the help and tutoring of teachers and experts, and not the other way around. This dynamic allows the students themselves to develop their own priorities [52] when defining the design of the Architectural Project they are developing, so that they constitute unrenounceable requirements that nourish and condition the Project and not mere declarations of intent without further development.

After the development of the workshop, specialization groups are established within the Aura Team to work on the most relevant issues and their application to the proposal.

\subsubsection{Generation of the SD-SDGs Aura Matrix Interrelationship}

The matrix tool that enables the SDGs to be related to the project design proposal for the SDLat 19 competition is built by defining the 28 strategic lines through the mentioned methodological process of awareness-raising, interiorization, conceptual debate and proposal of the priority strategies that will define the project. This matrix (Figure 3) allows us to verify during the debate and decision making about the strategic lines that all aspects are present and have been taken into account.

These 28 strategic lines, grouped into seven topics (Figure 4), constitute the design basis of the SDLat19 project. Design decisions based on them define the formulation of potential situations of habitability, in terms of comfort and health, and a more sustainable management of the urban space. The architects cannot decide for the user-citizen, but they can design the appropriate conditions of habitability and spatial quality, as well as a more sustainable management, which will incite an improvement in the user-citizen's quality of life [41].

\subsubsection{Development of the Aura Proposal for the SD 2019 Latin America Competition}

The design process of the Aura Proposal SDLat19 starts from the 28 strategic lines developed thanks to the Aura Method, and is part of the first stage of the process defined by the competition itself and adopted by the Aura Team. Thanks to the involvement of experts and a cross-discipline approach, to the integrated curriculum approach [52] and to the holistic approach provided by the Aura Method, the project design process incorporates educationally the explicit translation of the SDGs into architectural design decisions. 


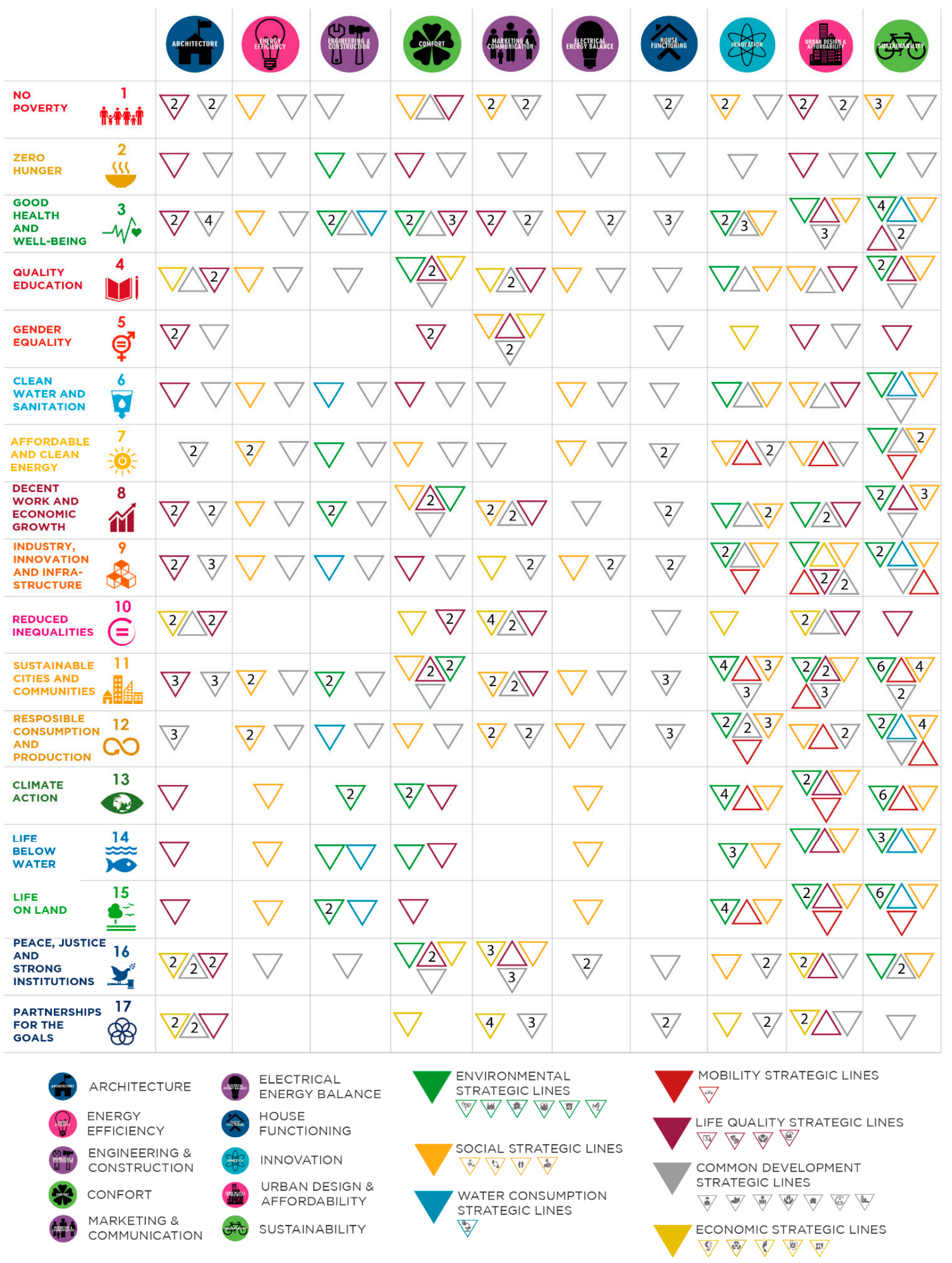

Figure 3. Aura Matrix, 28 strategic lines grouped into seven topics (each with a different color). The numbers inside the triangles indicate the number of specific strategies within the same topic. Source: the authors. 

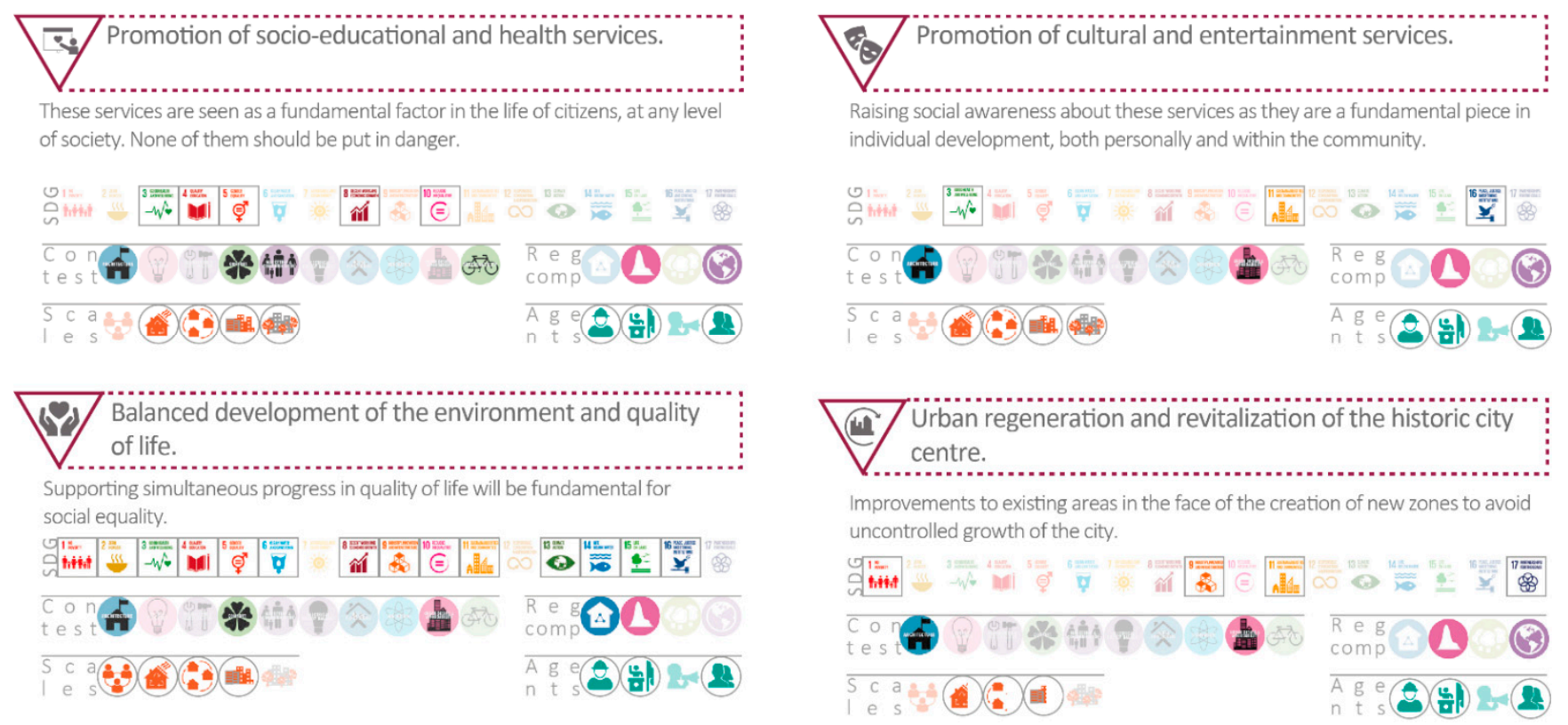

Figure 4. Example of a scheme for checking requirements and relations defined from the Aura Matrix for every strategic line, in this case four life quality strategic lines. Source: the authors.

\section{Results}

\subsection{Aura SD Latin America Project 2015}

The Solar Decathlon Latin America and Caribbean competition took place in Santiago de Cali (Colombia) in December 2015. For the first time in the competition, the characteristics of social housing, high-density construction, rational use of natural resources and regional relevance were required, guiding the proposals toward a sustainable social housing solution in Latin America.

The city of Santiago de Cali has a large housing deficit, and the macroproject area of the National Social Interest for the Eco-city of Navarro, a possible area of expansion of public property, has been selected for the development of the proposal [53]. The model of urban growth of the city proposed for Eco-Navarro consists in an organic development where an organized urban fabric will be developed and diluted in a natural space. Thus, the starting point emerges from the edge condition of this location, a meeting point between the city consolidated through the commune 15 and the natural environment of the wetland of the Corregimiento Navarro. The aim is to turn it into a support for an efficient and differentiated habitability (eco-neighborhood) for all the inhabitants of Cali, responding to its favorable and unfavorable conditions. The team aims to tackle the need to provide a solution to the transition space (Eco-Navarro) generated between the city and the eco-park.

Different modes of occupation and relationship with the territory are established through different densities of occupation, which respond to the diversification of neighborhood units (communities) and their location in specific enclaves of the area, attending to different relative and strategic positions in relation to that edge of the city. In each case they have their own articulation elements: a connection with existing or new infrastructures (jetties), treatments of the intermediate spaces between the room, the community and the urban sector to which they belong (social gardens, cooperative workshops, proximity commercial areas, leisure and health points).

The concept of the Equipped Park emerges as a cord, the backbone of the city. Different individual green areas will appear and give rise to communities. These communities will alter the dimensions of the Equipped Park. 
The proposal sets in motion a process in which the occupation of this territory, a unique place in the city of Cali, and the traditional and emerging ways of Cali lifestyles go together. The aim is to achieve an efficient housing development based on an agreement between the social interests of various communities and the place itself, preserving its nature, solving its dysfunctions and enhancing its activity in relation to the city and the citizens of Cali. To this end, certain social programs for the promotion and acquisition of housing in Corregimiento Navarro and a mixed program for the rental of social housing and workshops on public promotion premises are proposed as complementary measures. A sustainable city is not only based on the creation of communities in which buildings are sustainable in terms of energy consumption, but also on needs and an economy that allow for the personal development of individuals, linked to the generation of activity and social programs to avoid social exclusion.

\subsection{Aura SD Latin America Project 2019}

On this occasion, the project is proposed for the district of Siloé, in Cali, Colombia, due to the problems and deficiencies found there, which make it an object of study. It is a self-built district, which allows for the subsequent extrapolation of the Aura Strategy to other situations. The proposed solutions aim to make Siloé a sustainable social and healthy habitat for everyone.

The main innovation of the proposal is that, in this case, we start from a reality that has already been built. Instead of expanding the city beyond its limits or demolishing districts to build them from scratch, the urban fabric is improved with participatory decisionmaking strategies. The concepts of reuse and recycling of what has already been built are the foundations of the Aura 3.1 proposal. The project starts from the idea of transforming an existing base through fragmented objects and unfinished actions. Thus, the convenience of thinking about interventions made up of fragments as a more realistic and viable option is claimed, as opposed to the unfeasibility, in the current socioeconomic context, of a total renovation of what has been built. This way of intervening, through fragments, will allow for the transformation of a deficient, unhealthy and obsolete starting situation, which no longer responds to current requirements, through microactions that effectively resolve concrete questions linked to contemporary ways of living.

The focus of the approach at the general level arises from the strategy of recovering and valuing the socio-ecosystem support underlying the same neighborhood. To do this, we must work with the 'neighborhood' ecosystem in terms of controlling energy cycles and material resources, and complement it with an inclusive social management strategy that allows its development to become more sustainable over time.

We value the underlying ecosystem, starting from the local water system as a network that allows us to close fundamental material cycles and link them to local energy management by improving both urban and building habitability in terms of comfort and health, linked to climate adaptation and the use of natural energies.

In terms of energy management, the fundamental regenerative strategy is urban naturalization with native species. This strategy allows us to improve air quality, contributing positively to health, to control solar radiation and to reorganize the water cycle, by improving the general habitability of the urban space and the buildings.

In terms of material cycle management, the work is done mainly on the water and soil. Soil management is carried out respecting the building and urban pre-existence, but specifically regenerating those representative points that allow for an autonomous dynamic leading to a subsequent regeneration of the neighborhood.

For an inclusive social management strategy, the services generated from the two previous managements are ultimately defined by the users through participatory strategies, whose nerve centers are the 'Digital Creation Civic Centers', based on the proposals previously defined in terms of health, training, social development and cultural identity.

The 'Aura 3.1' building rehabilitation proposal is configured from a series of specialized devices (fragments/gadgets) capable of coupling to obsolete buildings, which 
need to be transformed to meet the new living needs of contemporary society. These gadgets are designed, projected and built in the Digital Creation Civic Centers, with citizen participation and with the resources of the nearby industrial fabric. In this way, products and sub-products from the environment are used, promoting recycling and generating, in addition to jobs, the appropriation of the actions by the people of the neighborhood.

These fragments could be included in the following groups:

- Housing units

- Structural elements

- Improvements in water management

- Energy improvements: ventilated plant enclosures and daylighting improvement systems

- Incorporation of Recycling Cycles

- Treatment of public spaces: recovery of roofs as common spaces, accessibility elements, plant elements, natural retaining walls with recycled material from demolitions (gabions).

The city is reactivated through small interventions, so the economic cost compared to a newly built project is significantly lower.

\section{Discussion}

Comparison of Results between the Aura Solar Decathlon Latin America and Caribbean Projects 2015 and 2019

Once the process has been analyzed by comparing the results obtained in terms of the conceptualization of urban architectural design and the design of the specific urban proposal in relation to the SDGs framework, several conclusions can be established.

From a conceptual point of view, the proposal for SDLat2019 is more appropriate, daring and innovative, since it assumes the built heritage as an undeniable base on which to work, immediately stopping the depredation of the territory with the increase in the extension of the urban fabric. On the other hand, this strategy highlights the value of the urban landscape made up of the most disadvantaged neighborhoods, which are abundant in the Latin American context, and makes it possible to channel their opportunities in terms of greater sustainable development [2], despite their initial differential situation [31].

Both proposals, SDLat15 and SDLat19, improve land use conditions regarding more intensive building densities needed to promote a more compact city and, with it, the advantages in terms of urban metabolism and mobility. The difference lies in the level of social commitment, which in the second case is more in line with an improvement in the social fabric of the involved community.

Both proposals significantly include and adequately resolve energy, material and resource management, linking it in both cases to the management of the supporting ecosystem. The improvement in the SDLat19 proposal lies, once again, in the potential social use, both educational and professional, linked to the management of these resources. This potential social use reinforces the resilience of the neighborhood, not only by improving health aspects related to physical comfort but also by improving psychological comfort, empowering citizens and creating a more creative, resilient and healthy environment [48].

The achievements related to the SDGs that can be drawn from the decisions of the urban architectural project design of both proposals are defined below (Table 1). 
Table 1. Comparative results of SDLat15 and SDLat19 for each SDG.

\begin{tabular}{ll}
\hline \multicolumn{1}{c}{ SDG } & \multicolumn{1}{c}{ SDLat15 } \\
\hline $\begin{array}{l}\text { Goal 1: End poverty in all its forms } \\
\text { everywhere }\end{array}$ & \\
\hline $\begin{array}{l}\text { Goal 2: End hunger, achieve food security } \\
\text { and improved nutrition and promote } \\
\text { sustainable agriculture }\end{array}$ & $\begin{array}{l}\text { Urban gardens for self-consumption, } \\
\text { collective management }\end{array}$ \\
\hline $\begin{array}{l}\text { Goal 3: Ensure healthy lives and promote } \\
\text { well-being for all at all ages }\end{array}$ & $\begin{array}{l}\text { Improved health in new development for } \\
\text { relocated people }\end{array}$ \\
\hline $\begin{array}{l}\text { Goal 4: Ensure inclusive and equitable } \\
\text { quality education and promote lifelong } \\
\text { learning opportunities for all }\end{array}$ & \\
\hline
\end{tabular}

Inclusion of the population in professional educational programs

Goal 5: Achieve gender equality and empower all women and girls

Urban gardens for self-consumption, collective and/or family management

Improvement of health in the existing city, in terms of physical and psychological comfort and habitability

Social educational centers, universal Wi-Fi access, professional training linked to the regeneration of the city

Participatory involvement of ALL inhabitants. Improvement of urban safety conditions. Enhancing the value of domestic work

Goal 6: Ensure availability and sustainable management of water and sanitation for all

In the new urban development

In the existing city, improving health and quality of life conditions

Goal 7: Ensure access to affordable, reliable, sustainable and modern energy for all

Renewable energies in new development, high energy efficiency

Improvement of the energy efficiency of what already exists. Programs for the incorporation of renewables, professional specialization in energy management

Goal 8: Promote sustained, inclusive and sustainable economic growth, full and productive employment and decent Potential works during the construction of the new urban development

Vocational training for intervention in existing neighborhoods. Construction level, energy level, urban nature, sanitation, etc.

Goal 9: Build resilient infrastructure, promote inclusive and sustainable industrialization and foster innovation

Goal 10: Reduce inequality within and among countries

Work for the city's most disadvantaged population

Contribution to the local industry, valuing the artisanal.

Work for and with the city's most disadvantaged population

Goal 11: Make cities and human settlements inclusive, safe, resilient and sustainable

Replacing situations of exclusion with quality city situations

Transforming situations of exclusion into quality city opportunities

Goal 12: Ensure sustainable consumption and production patterns

Improvement of consumption conditions linked to buildings

Educational improvement linked to consumption and production patterns for application in neighborhood regeneration

Practical education in efficient buildings in terms of energy management, water cycle, land management, urban green management and material resources management, water cycle and materia

Control in water management in order to
Improved control in water management to prevent pollution in seas and oceans. Education in terms of waste management resources prevent pollution in seas and oceans
Goal 14: Conserve and sustainably use for sustainable development

Efficient buildings in terms of energy

Goal 13: Take urgent action to combat climate change and its impacts 
Table 1. Cont.

\begin{tabular}{|c|c|c|}
\hline SDG & SDLat15 & SDLat19 \\
\hline $\begin{array}{l}\text { Goal 15: Protect, restore and promote } \\
\text { sustainable use of terrestrial ecosystems, } \\
\text { sustainably manage forests, combat } \\
\text { desertification, and halt and reverse } \\
\text { land degradation and halt } \\
\text { biodiversity loss }\end{array}$ & $\begin{array}{l}\text { Proper integration into the territory and } \\
\text { correct use of the ecosystem }\end{array}$ & $\begin{array}{l}\text { Recovery of the support ecosystem and } \\
\text { cessation of the depredation of the } \\
\text { territory }\end{array}$ \\
\hline $\begin{array}{l}\text { Goal 16: Promote peaceful and inclusive } \\
\text { societies for sustainable development, } \\
\text { provide access to justice for all and build } \\
\text { effective, accountable and inclusive } \\
\text { institutions at all levels }\end{array}$ & $\begin{array}{l}\text { Improvement of urban social conditions } \\
\text { that allow the population to be compared } \\
\text { to other neighborhoods in the city }\end{array}$ & $\begin{array}{l}\text { Improving governance by empowering } \\
\text { citizens }\end{array}$ \\
\hline $\begin{array}{l}\text { Goal 17: Strengthen the means of } \\
\text { implementation and revitalize the Global } \\
\text { Partnership for Sustainable Development }\end{array}$ & $\begin{array}{l}\text { Collaboration between agents, citizens, } \\
\text { authorities and technicians }\end{array}$ & $\begin{array}{l}\text { Collaboration between agents, citizens, } \\
\text { authorities and technicians, prioritizing } \\
\text { the needs of the community }\end{array}$ \\
\hline
\end{tabular}

It can be seen from the obtained results that the applied methodology, and therefore the defined Aura Method as a process and the Aura Matrix used as a tool, have involved a transformation and an improvement of the design results obtained for the SdLat19 competition. The approach has been consolidated, but the method has allowed, in addition, for the specific definition of a process design that internalizes the SDGs and provides specific responses to them, as potential opportunities provided by the urban city design. The Aura Matrix is an innovative graphic tool that provides a holistic visualization of the whole situation and promotes complex decision making in a simple way, going further than previous partial approaches based on urban form [14] or general management policies [11]. Thus, the main goal of this research has been achieved and constitutes a step forward regarding new and growing practical and specific approaches that introduce the SDGs concept into architectural design practice and education $[15,52,54]$. The approach has allowed for the introduction of environmental as well as economic and social aspects, such as those linked to citizen participation [55], an achievement that finds its justification and support in the trans-disciplinary field of the urban approach.

With this methodology, the students have also been able to train autonomously, learn how to work in a team, join multidisciplinary teams and face problem-solving situations [2]. On the other hand, the importance given to the processes of participation and citizen empowerment in terms of governance, thanks to the method itself, constitutes a life learning process for students, beyond the architectural and urban planning discipline, and prepares them to be technicians with greater sensitivity and more competent to deal with SDGs in any personal or professional situation in which they may find themselves in the future, thus responding to the requirements defined by the Higher Education Sustainability Initiative (HESI) [27].

The present study has found a field of educational experimentation of great interest within the framework of the Solar Decathlon competitions [50,52]. However, the process defined as Aura Method and the Aura Matrix tool must be adapted, and their educational capacity analyzed in connection with the Architecture Degree Courses and the disciplines involved. It is necessary to continue research on educational issues and analyze and verify the possibilities that this methodological strategy and this tool—or others that may derive from it - can bring to everyday teaching [56], in order to guarantee the correct transversal incorporation of the SDGs in the curriculum of the universities [52] and in everyday professional practice [57].

\section{Conclusions and Possible Extrapolations}

The validity of the process, which managed to define a method with excellent results, the richness of the innumerable interdisciplinary and transdisciplinary situations presented 
along the way, and even the two-way learning between teachers and students, make this educational experiment an innovative demonstration of the translation of SDGs into architectural design project decisions, which are coherent with the current challenges we face in terms of health in particular and in terms of sustainable development of our cities in general.

Likewise, the framework of the experiment represented by the Solar Decathlon Competitions is stimulating as an opportunity for the students to get in touch with the most up-to-date concepts in the field developed in other universities and with the possibility of exchanging concerns, ideas, concepts and materializations. Fortunately, interesting international competitive initiatives targeting higher education students from all over the world have emerged in recent years, such as the Blue Award [58], the Lafarge Holcim Awards for Sustainable Construction [59], the Architecture at Zero Competition [60], the Fassa Bortolo International Prize for Sustainable Architecture, on its 13th Edition [61], the 2020 ASHRAE Design Competition [62] or the Reinventing Cities Competition [63]. Some of these competitions, such as the one presented here, provide an exceptional framework for the exchange of information and an effective forum for the transmission of knowledge and idealizations generated in the academic world.

This proposed method and tool constitute a working base for research in educational matters, which can be extrapolated to all types of international competitive initiatives, such as those described above, since its adaptability is immediate and simple. The Aura Matrix tool is a reference in terms of the translation and applicability of complex and interdisciplinary concepts to the architectural design decisions of the discipline. Its application must be accompanied by a solid and rigorous educational process defined by the Aura Method, which encourages researchers not only to work on the visibility and development of technical knowledge but also to continuously put potential design decisions in relation to the perceptions of transversal disciplines, conjunctural problematic situations such as the current pandemic and the changing needs and priorities of citizen collectives.

This initiative should serve as a starting point to gradually bring about a change in the approach to university teaching methodology, which should not only be adapted to the reality of the profession, but also aligned, like other administrations, with the requirements launched by international organizations, such as the 2030 Agenda and the 17 SDGs.

From the design point of view, even outside the academic field, the incorporation of the SDGs in the development of architectural and urban planning projects is a tool for sustainable and healthy design, an alternative to official sustainability certifications (BREEAM, LEED, VERDE, etc.) and differentiated by its more global nature, which presents an opportunity worldwide to reduce development inequalities between countries and contribute to the fulfilment of the 2030 Agenda.

Author Contributions: All authors have contributed equally to the investigation and final manuscript. conceptualization, R.H.-L., M.L., M.B.-J. and M.T.G.; methodology, R.H.-L., M.L., M.B.-J. and M.T.G.; validation, R.H.-L., M.L., M.B.-J. and M.T.G.; writing—original draft, R.H.-L., M.L., M.B.-J. and M.T.G. All authors have read and agreed to the published version of the manuscript.

Funding: This article is the result of a study in item FADIN 4.0, within the Research support program of the Campus of International Excellence Andalucía TECH, and was backed by the Government of Andalusia (Regional Ministry of Economy, Knowledge, Enterprise and University). The authors are grateful for the support.

Acknowledgments: The authors want to acknowledge all members of the Solar Decathlon Team of the University of Seville.

Conflicts of Interest: The authors declare no conflict of interest.

\section{References}

1. Secretaría de Habitat III. Nueva Agenda Urbana; Naciones Unidas: Quito, Ecuador, 2017.

2. Omer, M.A.B.; Noguchi, T. A conceptual framework for understanding the contribution of building materials in the achievement of Sustainable Development Goals (SDGs). Sustain. Cities Soc. 2020, 52, 101869. [CrossRef] 
3. Alawneh, R.; Ghazali, F.; Ali, H.; Sadullah, A.F. A Novel framework for integrating United Nations Sustainable Development Goals into sustainable non-residential building assessment and management in Jordan. Sustain. Cities Soc. 2019, 49, 101612. [CrossRef]

4. Galli, A.; Đurović, G.; Hanscom, L.; Knežević, J. Think globally, act locally: Implementing the sustainable development goals in Montenegro. Environ. Sci. Policy 2018, 84, 159-169. [CrossRef]

5. Fukuda-Parr, S.; Muchhala, B. The Southern origins of sustainable development goals: Ideas, actors, aspirations. World Dev. 2020, 126, 104706. [CrossRef]

6. Chirambo, D. Towards the achievement of SDG 7 in sub-Saharan Africa: Creating synergies between Power Africa, Sustainable Energy for All and climate finance in-order to achieve universal energy access before 2030. Renew. Sustain. Energy Rev. 2018, 94, 600-608. [CrossRef]

7. Botchwey, N.D.; Trowbridge, M.; Fisher, T. Green Health: Urban Planning and the Development of Healthy and Sustainable Neighborhoods and Schools. J. Plan. Educ. Res. 2014, 34, 113-122. [CrossRef]

8. Campagnolo, L.; Davide, M. Can the Paris deal boost SDGs achievement? An assessment of climate mitigation co-benefits or side-effects on poverty and inequality. World Dev. 2019, 122, 96-109. [CrossRef]

9. McArthur, J.W.; Rasmussen, K. Classifying Sustainable Development Goal trajectories: A country-level methodology for identifying which issues and people are getting left behind. World Dev. 2019, 123, 104608. [CrossRef] [PubMed]

10. Etinay, N.; Egbu, C.; Murray, V. Building Urban Resilience for Disaster Risk Management and Disaster Risk Reduction. Procedia Eng. 2018, 212, 575-582. [CrossRef]

11. França, A.S.L.; Amato Neto, J.; Gonçalves, R.F.; Almeida, C.M.V.B. Proposing the use of blockchain to improve the solid waste management in small municipalities. J. Clean. Prod. 2020, 244, 118529. [CrossRef]

12. Opoku, A. Biodiversity and the built environment: Implications for the Sustainable Development Goals (SDGs). Resour. Conserv. Recycl. 2019, 141, 1-7. [CrossRef]

13. Diaz-Sarachaga, J.M.; Jato-Espino, D.; Castro-Fresno, D. Is the Sustainable Development Goals (SDG) index an adequate framework to measure the progress of the 2030 Agenda? Sustain. Dev. 2018, 26, 663-671. [CrossRef]

14. Jabareen, Y.R. Sustainable urban forms: Their typologies, models, and concepts. J. Plan. Educ. Res. 2006, 26, 38-52. [CrossRef]

15. Sen, S.; Umemoto, K.; Koh, A.; Zambonelli, V. Diversity and Social Justice in Planning Education: A Synthesis of Topics, Pedagogical Approaches, and Educational Goals in Planning Syllabi. J. Plan. Educ. Res. 2017, 37, 347-358. [CrossRef]

16. Saha, D.; Paterson, R.G. Local government efforts to promote the "Three Es" of sustainable development: Survey in medium to large cities in the United States. J. Plan. Educ. Res. 2008, 28, 21-37. [CrossRef]

17. León-Rodríguez, A.L.; Suárez, R.; Bustamante, P.; Campano, M.A.; Moreno-Rangel, D. Design and Performance of Test Cells as an Energy Evaluation Model of Facades in a Mediterranean Building Area. Energies 2017, 10, 1816. [CrossRef]

18. Domínguez-Amarillo, S.; Fernández-Agüera, J.; Peacock, A.; Acosta, I. Energy related practices in Mediterranean low-income housing. Build. Res. Inf. 2020, 48, 34-52. [CrossRef]

19. Camporeale, P.E.; Mercader-Moyano, P. Towards nearly Zero Energy Buildings: Shape optimization of typical housing typologies in Ibero-American temperate climate cities from a holistic perspective. Sol. Energy 2019, 193, 738-765. [CrossRef]

20. Alawneh, R.; Mohamed Ghazali, F.E.; Ali, H.; Asif, M. Assessing the contribution of water and energy efficiency in green buildings to achieve United Nations Sustainable Development Goals in Jordan. Build. Environ. 2018, 146, 119-132. [CrossRef]

21. United Nations General Assembly. Seventy-First Session Agenda Item 20 Implementation of the Outcomes of the United Nations Conferences on Human Settlements and on Housing and Sustainable Urban Development and Strengthening of the United Nations Human Settlements Programme (UN-Habitat) Dr; Naciones Unidas: Quito, Ecuador, 2016. Available online: http://habitat3.org/wpcontent/uploads/N1639668-English.pdf (accessed on 14 April 2020).

22. Kooy, M.; Walter, C.T.; Prabaharyaka, I. Inclusive development of urban water services in Jakarta: The role of groundwater. Habitat Int. 2018, 73, 109-118. [CrossRef]

23. Schwartz, K.; Gupta, J.; Tutusaus, M. Editorial-Inclusive development and urban water services. Habitat Int. 2018, 73, 96-100. [CrossRef]

24. Serag El Din, H.; Shalaby, A.; Farouh, H.E.; Elariane, S.A. Principles of urban quality of life for a neighborhood. HBRC J. 2013, 9 , 86-92. [CrossRef]

25. Gharib, M.A.; Golembiewski, J.A.; Moustafa, A.A. Mental health and urban design-Zoning in on PTSD. Curr. Psychol. 2020, 39, 167-173. [CrossRef]

26. Forero La Rotta, A.; Ospina Arroyave, D. Estrategia didáctica para el aprendizaje de la historia y la teoría de la arquitectura. Rev. De Arquit. 2013, 15, 78-83. [CrossRef]

27. Boarin, P.; Martinez-Molina, A.; Juan-Ferruses, I. Understanding students' perception of sustainability in architecture education: A comparison among universities in three different continents. J. Clean. Prod. 2019, 119237. [CrossRef]

28. ONU-Habitat. Estado de las Ciudades de América Latina y el Caribe 2012. Rumbo a una Nueva Transición Urbana; Programa de las Naciones Unidas para los Asentamientos Humanos: Rio de Janeiro, Brazil, 2012; ISBN 978-92-1-133397-8/978-92-1-132469-3.

29. United Nations Development Group for Latin America \& Caribbean (UNSDG). Desarrollo sostenible en América Latina y el Caribe: Desafíos y ejes de Política Pública; Naciones Unidas: Panama City, Panama, 2018.

30. United Nations. Transforming our World: The 2030 Agenda for Sustainable Development; United Nations: Quito, Ecuador, 2015. 
31. Sheth, S.; Bettencourt, L.M.A. The Community Human Development Index (CHDI): Localizing Sustainable Development Goals across Scales. 2020 IEEE Conf. Technol. Sustain. 2020. [CrossRef]

32. Steinemann, A. Implementing sustainable development through problem-based learning: Pedagogy and practice. J. Prof. Issues Eng. Educ. Pract. 2003, 129, 216-224. [CrossRef]

33. Iborra, C. Lo que NO hacen los mejores profesores universitarios. Vivat Acad. 2007, 1. [CrossRef]

34. Neuhauser, L.; Pohl, C. Integrating Transdisciplinarity and Translational Concepts and Methods into Graduate Education. In Transdisciplinary Professional Learning and Practice; Gibbs, P., Ed.; Springer: Cham, Switzerland, 2015.

35. Barrette, C.M.; Paesani, K.; Vinall, K. Toward an integrated curriculum: Maximizing the use of target language literature. Foreign Lang. Ann. 2010, 43, 216-230. [CrossRef]

36. Jæger, K. New-Style Higher Education: Disciplinarity, Interdisciplinarity and Transdisciplinarity in the EHEA Qualifications Framework. High. Educ. Policy 2018, 1-20. [CrossRef]

37. Moreno Toledano, L.A. Abordar lo complejo desde el diseño: Una mirada hacia la transdisciplinariedad. Educ. Y Humanismo 2017, 19, 369-385. [CrossRef]

38. Chau, K.W. Incorporation of sustainability concepts into a civil engineering curriculum. J. Prof. Issues Eng. Educ. Pract. 2007, 133, 188-191. [CrossRef]

39. Herrera-Limones, R.; León-Rodríguez, Á.L.; López-Escamilla, Á. Solar Decathlon Latin America and Caribbean: Comfort and the balance between passive and active design. Sustain. (Switz.) 2019, 11, 3498. [CrossRef]

40. Korobar, V.P.; Siljanoska, J. Challenges of teaching sustainable urbanism. Energy Build. 2016, 115, 121-130. [CrossRef]

41. López-Escamilla, Á.; Herrera-Limones, R.; León-Rodríguez, Á.L.; Torres-García, M. Environmental comfort as a sustainable strategy for housing integration: The aura 1.0 prototype for social housing. Appl. Sci. (Switz.) 2020, 10, 7734. [CrossRef]

42. Wen, B.; Musa, S.N.; Chuen, C.; Ramesh, S.; Liang, L.; Wang, W.; Ma, K. The role and contribution of green buildings on sustainable development goals. Build. Environ. 2020, 185, 107091. [CrossRef]

43. Alexander, C. Tres Aspectos de Matemática y Diseño; y La Estructura del Medio Ambiente, 2nd ed.; Cuadernos Infimos. Serie Arquitectura y Diseño 3; Tusquets: Barcelona, Spain, 1980; ISBN 84-7223-405-3.

44. Herrera-Limones, R. La Urdimbre Sostenible como Táctica para un Hacer Arquitectónico: De la "Arquitectura de Países Cálidos" Hasta los Nuevos Escenarios y Modos de vida Emergentes, a Través de la Dimensión Dialógica. 2013. Available online: https:/ /idus.us.es/handle/11441/36339 (accessed on 4 June 2021).

45. De Manuel Jerez, E. Construyendo triángulos para la gestión social del hábitat Abstract: Constructing triangles for social management of habitat Key words. Hábitat Y Soc. 2010, 1, 13-37. [CrossRef]

46. Xiong, W.; Chen, B.; Wang, H.; Zhu, D. Public-private partnerships as a governance response to sustainable urbanization: Lessons from China. Habitat Int. 2020, 95. [CrossRef]

47. Freire, J. Urbanismo emergente: Ciudad, tecnología e innovación social - Emerging urban planning: City, technology and social innovation. In Paisajes Domésticos/Domestic Landscapes, Vol. 4 Redes de Borde/Edge Networks; SEPES Entidad Estatal de Suelo, España: Madrid, Spain, 2009; Volume 4, pp. 18-27.

48. Jackson, L.E. The relationship of urban design to human health and condition. Landsc. Urban Plan. 2003, 64, 191-200. [CrossRef]

49. Herrera-Limones, R.; Pineda, P.; Roa, J.; Cordero, S.; López-Escamilla, A. Project AURA: Sustainable social housing. In Sustainable Development and Renovation in Architecture, Urbanism and Engineering; Mercader Moyano, P., Ed.; Springer International Publishing: New York, NY, USA, 2017; pp. 277-288; ISBN 978-3-319-51442-0.

50. Luna-Tintos, J.F.; Cobreros, C.; Herrera-Limones, R.; López-Escamilla, A. Methodology comparative analysis in the solar decathlon competition: A proposed housing model based on a prefabricated structural system. Sustain. (Switz.) 2020, 12, 1882. [CrossRef]

51. Villate, C.; Tamayo, B. La práctica de la arquitectura como racionalización sistémica. Dearq 2010, 178-199. [CrossRef]

52. Herrera-Limones, R.; Rey-Pérez, J.; Hernández-Valencia, M.; Roa-Fernández, J. Student competitions as a learning method with a sustainable focus in higher education: The University of Seville "Aura Projects" in the "Solar Decathlon 2019". Sustainability 2020, 12, 1634. [CrossRef]

53. Herrera-Limones, R.; Gómez, I.; Borrallo, M.; De la Iglesia, F.; Domínguez, A.; Gil, M.A.; Roa, J.; López, E.; Granados, M. Solar Decathlon Latino América y Caribe. Cali 2015 (Colombia) Proyecto Aura. In Proceedings of the II International and IV National Congress on Sustainable Construction and Eco-Efficient Solutions/Congreso Internacional de Construcción Sostenible y Soluciones Ecoeficientes, Sevilla, Spain, 25-27 May 2017; pp. 769-794.

54. Kochan, D. The Prospects and Challenges of Socially Engaged Urban Planning and Architecture in Contemporary China. J. Plan. Educ. Res. 2018. [CrossRef]

55. LopezDeAsiain, M.; Díaz-García, V. The Importance of the Participatory Dimension in Urban Resilience Improvement Processes. Sustainability 2020, 12, 7305. [CrossRef]

56. LopezDeAsiain, M.; Díaz-García, V. Estrategias educativas innovadoras para la docencia teórica en Arquitectura. In Proceedings of the JIDA'20. VIII Jornadas sobre Innovación Docente en Arquitectura, Málaga, Spain, 12-13 November 2020; pp. 117-127.

57. Borrallo-Jiménez, M.; LopezDeAsiain, M.; Herrera-Limones, R.; Lumbreras Arcos, M. Towards a circular economy for the city of seville: The method for developing a guide for a more sustainable architecture and urbanism (GAUS). Sustain. (Switz.) 2020, 12, 7421. [CrossRef]

58. Department for Spatial and Sustainable Design. Vienna University of Technology Blue Award: International Student Competition for Sustainable Architecture. Available online: http:/ / www.blueaward.at/home.html (accessed on 18 April 2020). 
59. LafargeHolcim Foundation 6th Awards Cycle: 2020-2021 I Lafarge Holcim Foundation for Sustainable Construction. Available online: https: / www.lafargeholcim-foundation.org/awards/6th-cycle (accessed on 18 April 2020).

60. American Institute of Architects California (AIA CA) Architecture at Zero. 2020. Available online: http:/ /www.architectureatzero. $\mathrm{com} /$ (accessed on 18 April 2020).

61. Department of Architecture of University of Ferrara Italy Thirteenth International Prize for Sustainable Architecture Fassa Bortolobuilt projects division. Available online: https:/ / www.archdaily.com/906316/thirteenth-international-prize-for-sustainablearchitecture-fassa-bortolo-built-projects-division (accessed on 18 April 2020).

62. ASHRAE 2020 Integrated Sustainable Building Design (ISBD) Competition. Available online: https://www.ashrae.org/ communities/student-zone/competitions/2020-design-competition (accessed on 18 April 2020).

63. C40 Cities Climate Leadership Group Inc. Reinventing Cities Competition. Available online: https:/ / www.c40reinventingcities. org/en/about/ (accessed on 18 April 2020). 